\title{
JAPAN, MODERNITY AND THE TOKYO OLYMPICS
}

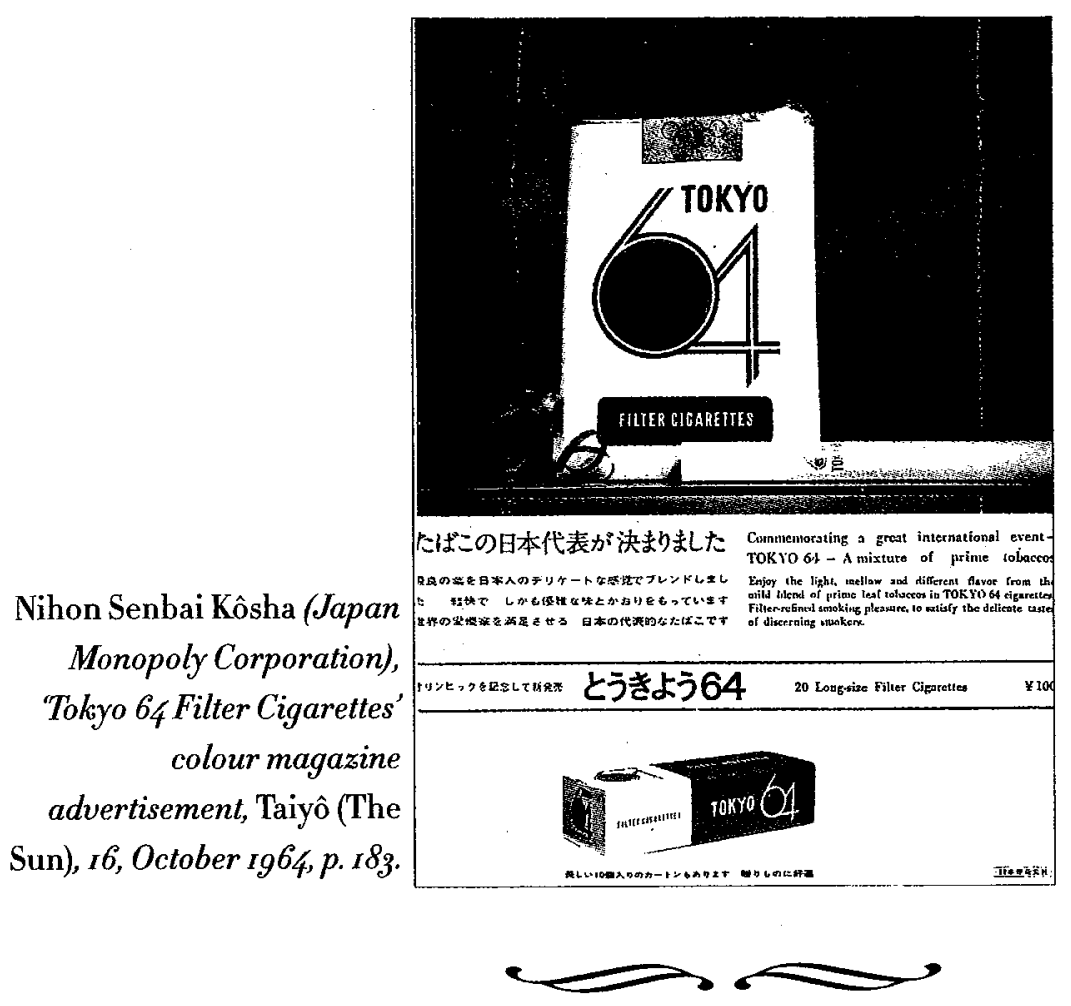

$\mathrm{H}$ modernity? This essay is an attempt to challenge the idea that modernity was simply viewed as an import from the West by specifically examining representations of Japan in major sporting events.' These representations often attempted to promote a syncretic image of Japan as a hybrid culture, one which borrowed from other nations and yet remained distinctive. Japan's industrialization unleashed modernizing social forces which eroded some local cultural differences but at the same time helped create a national identity. This identity was paradoxically linked not only with the nation's ability to borrow from other nations, internationalize and modernize, but also with the preservation of cultural traditions. In sport and other arenas, we see a code-switching between local and global worlds, a fluidity in identity, and a modernity of their own. ${ }^{2}$

The bodily experience of modernity in Japan has been shaped by the discourses of colonialism, militarism, and democracy. As Yoshio Sugimoto argues, these are not mutually exclusive. The cleaning of classrooms by students, group exercises reminiscent of army drills, emphasis on correct bowing and posture, and even etiquette regarding the blowing of noses contribute to what he describes as part of the friendly authoritarianism which 
pervades Japan today. ${ }^{3}$ By examining sport, we can gain some understanding of how this body culture evolved. In the name of sport and regional or global bonding, perceptions of racial and ethnic difference were sometimes downplayed. By looking specifically at Japan's participation in the Far Eastern Olympics of Ig23, the lead up to the cancelled r94o Tokyo Olympics, and the Games eventually held in 1964 , we can identify contending discourses of nationalism and internationalism.

Many Japanese publications were published in English as a form of cultural diplomacy to promote Japan in the West. By examining images of Japan in such publications, others consumed by the Japanese, and the images which visitors to Japan themselves went away with, we can glimpse an understanding of the greater transformations that Japan was undergoing. The film and photographs referred to in this essay are manifestations of certain visions of national culture and the role of tradition in it. Sporting images in the mass media helped define national identity for many Japanese.

Through the Olympics, Japan again embraced a modernity with prewar origins. ${ }^{4}$ In her recent book on Japan's Competing Modernities, Sharon

Minichiello stresses how ideas of modernity in prewar Japan pertained to progress, science, and rationality. 5 The 1940 Olympics which were to be held in Tokyo, and the 1964 Olympics which were, were both important moments in
Japanese history. They provide a window into the Japanese experience of modernity, and the tensions and contradictions inherent in it. In the years leading up to the Pacific War and those immediately after, there was a blending of both internationalism and nationalism in the discourses surrounding Japanese identity. As we shall see, in the immediate postwar period, the emphasis is on the former. The success of the Tokyo Olympics promoted a vision of 'Japaneseness' which emphasized the nation's modernity. Published accounts by foreign visitors reinforce this.

\section{BODY AND NATION}

In the late nineteenth century, foreign instructors helped introduce Western sports into the elite educational system in Japan. ${ }^{6}$ Differences in athletic ability were viewed as reflecting not only physical differences but differences in national strength. By promoting sport, they could improve the bodies of the Japanese. Sabine Frühstück has suggested that from the Meiji period (1868-1912) and the years leading up to the Pacific War, Japanese bureaucrats and intellectuals, physicians and scientists increasingly attempted to use scientific knowledge to form wellfunctioning and well-regulated bodies which could be mobilized for the nation.?

Yoshimi Shunya has examined Meiji schools as the space within which the nation was created and instilled in the bodies of children. Students underwent 
militaristic exercise drills and participated in athletics meets, a disciplinary technique which helped them form a sense of belonging to the state. ${ }^{8}$ Indeed, physical education was, for the Japanese and others, a way of linking the individual bodies of citizens to the welfare of the nation. ${ }^{9}$ There is still evidence of Meiji body culture in Japanese schools today.

Ikari Seiya argues that internationalism was a major characteristic of sport in the years after World War I and through to the I93os. The popularization of sports is evident from the pages of newspapers which still remain. In terms of Westerninspired sport activities in the late 1920 s and $3^{\circ}$, baseball was overwhelmingly the most popular, followed by sports such as athletics and swimming. ${ }^{10}$

\section{FAR EASTERN OLYMPICS}

Major sporting events add to national prestige, promote the interests of competitor nations through association with the performances of athletes, and create comparisons with other competitor nations. They provide cultural pleasure and impress visitors, and provide an effective instrument of propaganda. The historian Graeme Davison has argued that while celebrations such as the Olympics are opportunities to assert group identity and unity, on close inspection someone is excluded and something is being denied. ${ }^{\mathrm{II}}$ The Far Eastern Olympics, a series of major sporting events in which Japan, China, and the Philippines participated, were certainly a case of just that.
The Far Eastern Olympics were the idea of physical directors of the Manila and Shanghai YMCAs, who organized the Far Eastern Athletic Association with Japan to support the games. The games were held from 1913 to $19^{2} 7$ every two years, and after I930, every four years, alternating with the better-known world Olympic Games. As can be seen in media coverage of the Far Eastern Olympics held in Osaka, Japan, in I923 (see figure r), such athletics events provided the Japanese with a concrete example of Asian solidarity. Although the magazine pictured was written almost entirely for Japanese readers, a short

\section{FigURE I}

Track Event at the Sixth Far Eastern Olympics, Osaka, Japan, Ig23. Cover image, The Asahi Sports, I.5, May Igz3.

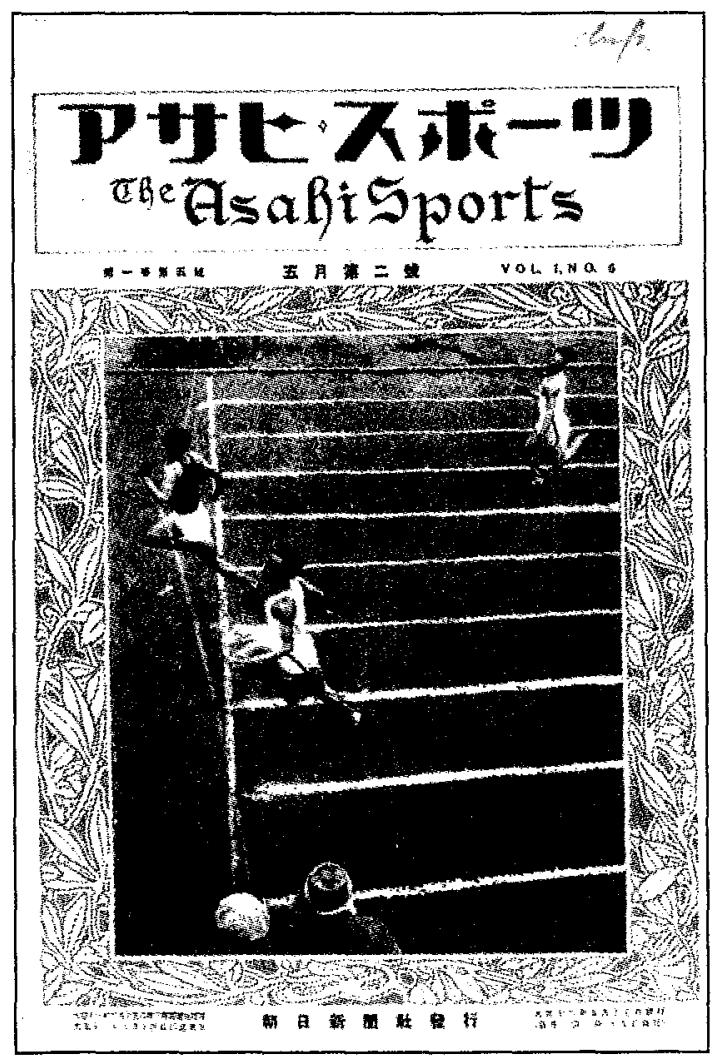


message of welcome could be found on the inside page, in English.

To the Philippino [sic] Champions, contestants in the Sixth Far Eastern Championship Games: The promotion of understanding and friendship between nations to-day can spring only from the open-hearted efforts made by each of the nations. For this reason we are gratified at knowing that the effectiveness of the friendly rivalry of sport and its essentiality in the cause of international peace are becoming recognized throughout the world. ${ }^{\text {I2 }}$

Maintaining this solidarity against the backdrop of Japanese territorial expansion strained relationships. Grant Goodman has written of the Far Eastern Olympics of I934. Japan sponsored Manchurian participation in the games that were to be held in Manila on 12-19 May. Japan insisted on the admission of the new informal colony of Manchukuo (formerly known as Manchuria) which, if successful, would have served to legitimate and recognize the new puppetstate. Japan had previously participated in the games and considerable press coverage had been devoted to it. China threatened to pull out of the games if Manchukuo was admitted. The 1934 Far Eastern Olympics went ahead without participation by Manchukuo, but shortly after the games were over, Japan and the Philippines agreed to dissolve the Far Eastern Athletic Association which was responsible for the games and in its place formed the Amateur Athletic Assocation of the Orient. This new organization included Manchukuo but excluded
China. ${ }^{13}$ This episode reflects the increasing politicization of sport in the r93os.

\section{FASCIST BODY CULTURE?}

Florence Taylor, an Australian who visited Japan in the I93os, could not help but link the body culture of Japan with that of Italy. In her book $A$ Pot-Pourri of Eastern Asia: With comparisons and reflections (1935), Taylor provides us with a sense of the importance of the health and well-being of the body and how that was seen as reflecting national might and military preparedness. A photograph in her book entitled 'Gymnastics in Italy' shows hundreds of men dressed in white undergoing a mass exercise drill. It bears the following caption:

In comparison, Australia trains her men and women in sports and in life-saving, which are worthy, but not nearly comprehensive enough to cope with defence demands. The onlookers should be trained as well. No success comes to a country just by chance. As with individuals, countries attract success by their thoughts and actions. ${ }^{14}$

This is preceded by a small illustration of young female Japanese archers in amongst the text, accompanied by a caption which describes how in Japan, 'according to' convention every step and every movement is governed by strict etiquette. Calm and complete control of mind and body are considered of greater importance than accuracy in shooting' ${ }^{15}$

Germany, Italy, and Japan do seem to have shared certain attitudes to the body which 
emphasized mass drills for both the civilian population and armed forces, and linked disciplining of the body and mobilization of the nation, but these attitudes were not unique to these nations. We can say, however, that sport in Italy played an important role in carrying out the Fascist Party's aims of patriotism and military fitness. At the outbreak of World War II, a major athletic stadium, the Forum Mussolini, was being completed for the I944 Olympic Games, which were cancelled. In Germany, physical education programs emphasized military objectives. Hitler youth clubs provided training in a range of sports including boxing, wrestling, swimming, and athletics. ${ }^{16}$ In Japan, Young Men's Leagues (seinendan) were also a way of promoting such activities. A 1937 publication on these organizations, written for a Western audience, suggested that while we might compare them to the YMCA, boy scout groups and Hitler Youth,

\begin{abstract}
There is no nation in the world that does not possess something prominently peculiar to its own land, which can hardly be copied by any other nation. And as these things are, in most cases, products of so-called racial instinct, quite natural and spontaneous, they always play one of the most fundamental roles that are essential to the development of national life, though even the nation itself sometimes has not a very clear idea of their significance. ${ }^{17}$
\end{abstract}

We should be careful not to stereotype attitudes to the body in Japan, for, as Florence Taylor suggested, countries such as Australia could benefit from such ideas as well. Even in Japan itself there were differing attitudes and intense debate on race in the years leading up to the Pacific War. ${ }^{18}$ And there is no consensus on whether we can label Japan as 'fascist'. 9

SPORT AND EMPIRE

In Japan: Her Cultural Development (r939), Kaji Ryûichi commented on the

FIGURE 2

Image of mass-drill in I93os Japan. The Society for International Cultural Relations, Sports, second impression (Tokyo: The Society, Ig3g).

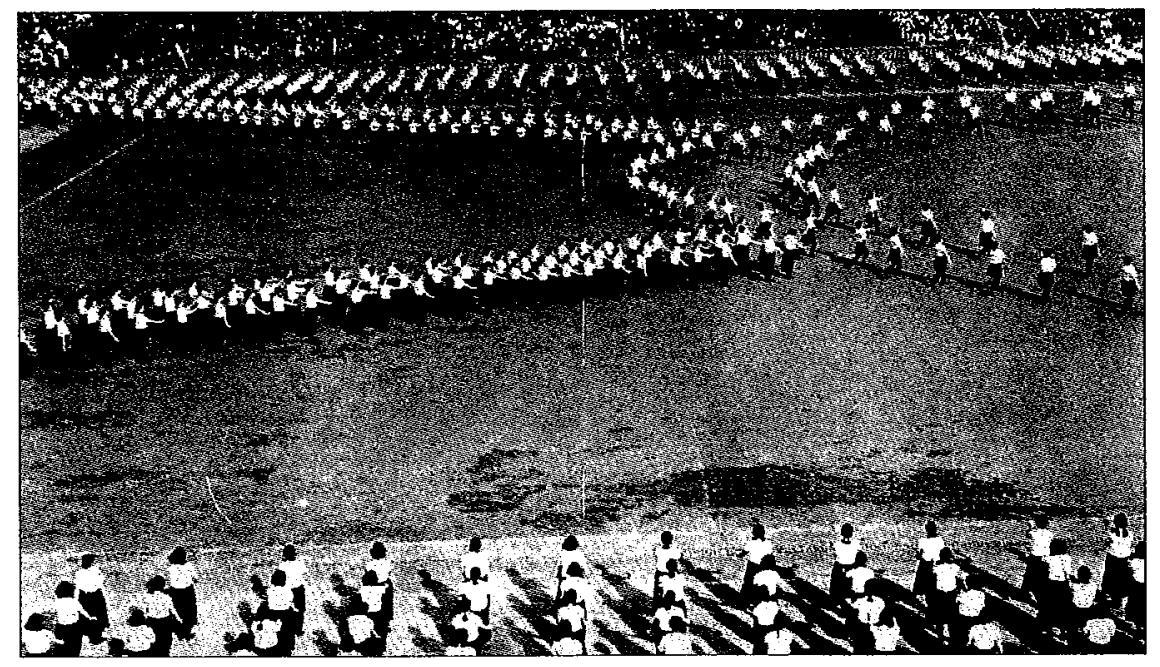


progress made by Japanese athletes and the need for political and economic advances as well:

Encouraged by international sport circles and improved by the coaching of foreign experts, Japanese athletes have made such progress in recent years that they often set new world records in track and water events. This means an advancement not only of Japanese, but also of world sport.... Of course such activity must not be limited to the cultural sphere, but must also be undertaken politically and economically. ${ }^{20}$

The first sentence is repeated as a caption to photos on the opposite page. It

diplomatically acknowledges the benefits of a modernity which owes much to other cultures, and the internationalism of sport, but nevertheless reminds readers of Japan's rights to protecting its national interests. The images show tennis courts, swimming pools (where the Japanese were excelling), and a mass exercise drill. While Japan acknowledges the benefits of internationalism, concerns regarding national ambitions are not far away. As Tani Barlow has reminded us, colonial and modernist discourses are often in collusion in Asia. ${ }^{21}$

In another English-language publication published by the same governmentfunded organization, The Society for

\section{Figure 3}

Boys Dressed in kendô (Japanese fencing) gear, r93os. The Society for International Cultural Relations, Sports, second impression (Tokyo: The Society, (939).

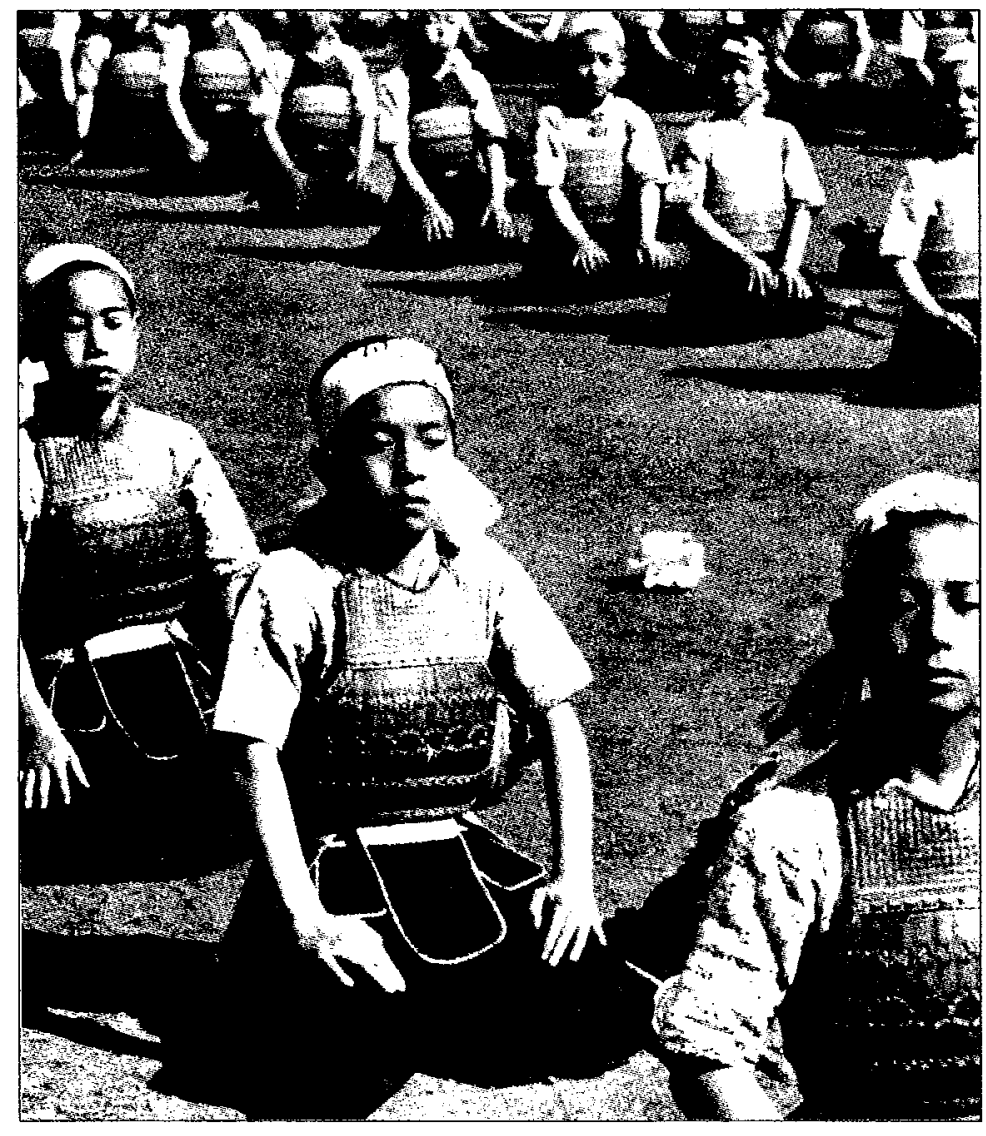


FiguRE 4

Japanese Hurdlers, 193os. The Society for International Cultural Relations, Sports, second impression (Tokyo: The Society, Ig39).

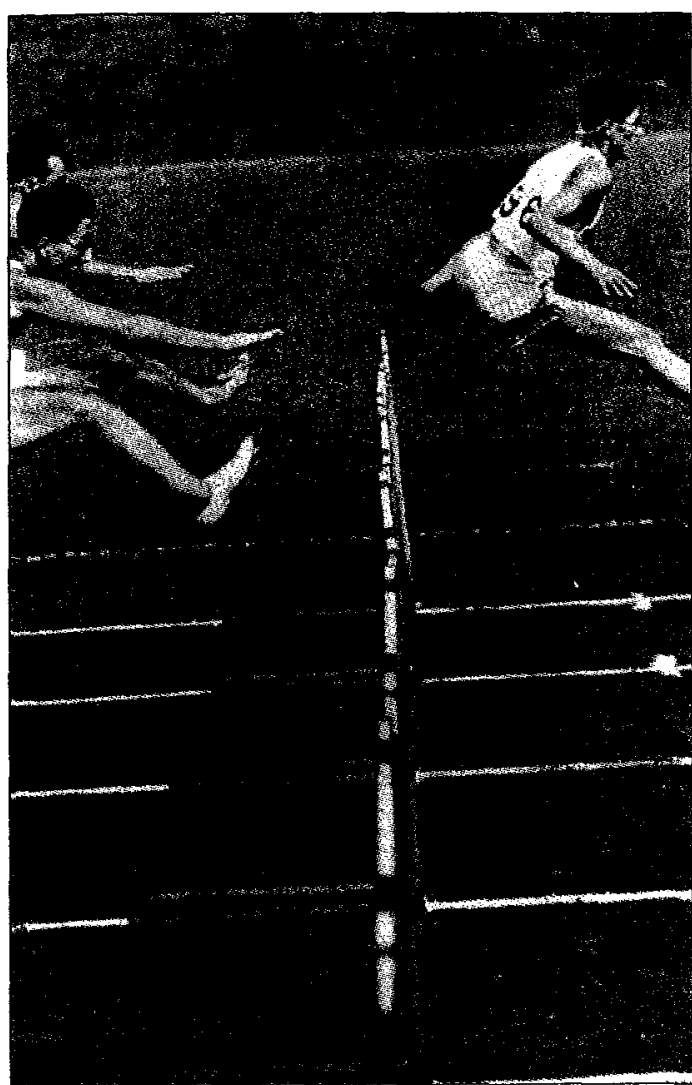

International Cultural Relations, that very same year, images of traditional sports.are juxtaposed with those of more recently introduced sports (see figures $3 \& 4$ ). The book entitled Sports was part of a series of heavily illustrated books on Japanese life and culture produced as part of a major effort at promoting Japanese culture in the USA and elsewhere in the years prior to the Pacific War. Captions to the images inform us that 'schools, factories, offices and other social institutions are trying to encourage physical culture through massdrills' (see figure 2) and that Kendô, Japanese fencing (see figure 3), was 'a moral code of the samurai and developed not only as a feat of the sword but as a means of spiritual cultivation'. While Japanese swimming, 'with the adaption of foreign strokes to the old Japanese forms' is seen as more of a hybrid sport, the result has 'come to be internationally famous'. Descriptions of Japanese sport reflect the growing militarization of physical culture in Japan, and the understanding that the Japanese drew on other cultures, preserved some of its traditions, and succeeded. ${ }^{22}$

The Japanese government has made extensive use of sports and culture for the pursuit of national purposes. Proposals to hold the Olympics in Tokyo can be viewed as part of Japanese 'cultural policy', with government officials seeking to use sporting events for the purposes of national policy and to reinforce Japan's right to compete with the world in territorial expansion.

\section{940 TOKYO OLYMPICS}

We cannot view the 1964 Olympics in isolation, for despite the changes Japan had undergone, the ghost of the cancelled I940 Tokyo Olympics (see cover) remained in the memories of many Japanese. The original proposal to schedule the Olympics in Tokyo directly after the 1936 Berlin Olympics, seemed to bond Germany and Japan. Tokyo was awarded the Olympics the day prior to the opening of the Games in Berlin in $193^{6}$, but by $193^{8}$, Japan's conflict with China and shortages in building materials, especially steel, meant 
that it had little option but to withdraw from hosting the Games. ${ }^{23}$

Kanô Jigorô (I860-I938) a pioneering figure in the development of jûdô and the Olympic movement in Japan reflected how Japanese could embrace both the old and new. He adapted techniques from various schools of the martial art of jûjutsu to form the basis of his new jûdô, a sport more grounded in the modern science of physiology and dynamics. He established the Japan Amateur Sports Association in IgIr as the body to select Olympic representatives, and he was instrumental in winning the 1940 Olympics for Tokyo. ${ }^{24}$

The Japanese Government also strategically planned to hold the International Exposition of Japan in $194^{\circ}$ at Tokyo and Yokohama, in order to commemorate the 2,60 oth anniversary of the accession to the throne of Emperor Jimmu, the first Emperor of Japan. The exposition would highlight 'the great achievements of Emperor Jimmu and his illustrious successors who have ruled over Japan in an unbroken line for twenty-six centuries. ${ }^{25}$ This was at a time of war with China and because of the political situation at the time, like the Olympics, did not come to fruition. It would not be until the postwar period when the first Tokyo Olympiad would be held.

The Olympics and Expo were major international events which, if held in 1940 , would have served to legitimate the Japanese empire. Almost a quarter of a century later, the Olympics served a different purpose-an opportunity to welcome Japan back to the family of nations and to celebrate its postwar reconstruction and economic growth. Both the prewar and postwar plans to hold the Olympics are evidence of the syncretism of Japanese culture in which a type of code-switching occurs.

Representations of Japanese identity can be fluid, and alternate between one rooted in Japanese (and Asian) traditions and one more closely linked with the West. ${ }^{26}$

\section{TECHNOLOGICAL DEVELOPMENT}

The Olympic Games were not only a celebration but also a stimulus for further technological development. Shin Mizukoshi has written of how the $194^{\circ}$ Olympics encouraged engineers to develop television technology in the hope of telecasting Japan's glory. The Olympics were to be but one of a number of national events which would feature television technology, from the late 193 os to the I940s. These included the Kôha Teishin Tenrankai' ('Asian Communications Exhibition'), 'Shisô Senden Tenrankai' ('Ideological Propaganda Exhibition'), and 'Kagayaku Gïutsu Tenrankai' (Brilliant Technology Exhibition'). ${ }^{27}$ While one might not immediately link the Olympics with technology and propaganda, in Japan's case there is a clear relationship.

The same confidence which prompted Japan's proposal to host the Olympics in I94o can also be seen in the development of railways. In prewar Japan, trains served 
as agents for Japanese expansion. A part of Japan's expansionist policy for Asia was the first 'bullet super-express' which was running by 1939 . Visitors to Manchukuo could apparently travel the $944 \mathrm{~km}$ between Dairen and Harbin in 12:5 hours by riding the 'stream-lined, ultra modern super-express “Asia”'. Reports describe it as having provided roomy, air-conditioned comfort for passengers, 'the last word in speed and comfort'. Maximum operating speed was said at the time to have been ${ }^{40}$ $\mathrm{km} / \mathrm{hr} .^{28}$ The early attempts to develop television (communications) and the very real expansion of railways (mass transporation) were part of attempts to establish in Japan the 'modern apparatus of circulation'. ${ }^{29}$ Such technologies worked to increasingly globalize the Japanese, introduced new forms of modernity, facilitated social cohesion and at the same time aided the movement and migration of people from Japan to other parts of the empire.

The dream of linking Japan via a highspeed train network continued into the postwar period. The construction of the new railway line was pushed forward, with the result that a commercial service started on I October 1964, the same year as the Olympic Games in Tokyo. Both served to heighten national prestige. $3^{\circ}$ The Japanese National Railways opened the new Tôkaidô Shinkansen (literally the ' Tôkaidô New Trunk Line') between Tokyo and Osaka ten days prior to the opening of the Olympic Games. The train has often been referred to as the 'bullet train' because of its high speed. ${ }^{3 r}$ The new Tôkaidô line was seen as a symbol of the modernization of Japanese railroads, and in a broader sense, Japan itself. Japan would take its rightful place in the 'sun', and the railways 'their rightful place alongside road and airline services' ${ }^{32}$ The coming of the second bullet train heralded a period of renewed Japanese confidence and was, in many respects, a manifestation of postwar Japanese techno-nationalism. Many agreed that the shinkansen embodied 'Utopian concepts which those modernizing an existing line can at best realize partially'. ${ }^{33}$ That it was realized just prior to the opening of the Olympics, at a time of high economic growth, is no historical accident.

The view from a shinkansen window became a central visual experience for travellers, an impressive reminder of Japan's modernity, especially its technological prowess. ${ }^{34}$ The train facilitated national cohesion, bringing even isolated regions and communities into contact with each other. Sport, too, brought people together, and one of the most successful examples of this was the I964 Tokyo Olympics.

\section{I9.64 TOKYO OLYMPICS}

The Olympics are not only opportunities for sporting fans to enjoy performances by athletes from throughout the world, they are also significant moments of representation and display.35 The noted Japanese director Ichikawa Kon captured 
those moments in his well-known film Tokyo Olympiad, sg64 (1965) for the Tôhô Film Company. Like Leni Riefenstahl's film of the $193^{6}$ Olympic Games Olympia (1938) which celebrated the body and the Nazi state,$^{36}$ it too had a message to convey to the rest of the world. By examining Ichikawa's portrayal of the Olympics, we can come to understand how the Games served a number of purposes for the Japanese. Japan had travelled a long way since its defeat in the Pacific War. The very same emperor who had broadcast his country's surrender less than two decades before, now greeted the countries of the world with pride. The historian Stephen Large has written that such events helped to sell the emperor to the Japanese public as the 'human emperor' ${ }^{37}$ Ichikawa's film further promoted the idea that the imperial household had adapted to postwar Japanese democracy by making connections between the previously sacred body of the emperor, the private moments of individual spectators, the sporting achievements of athletes and the masses who saw the film at the cinema.

For both those watching the Olympics in I964, and those participating, the Tokyo Olympics conjured up mixed feelings. These were embodied in the torch bearer, Sakai Yoshinori, who was born the day after the atomic bomb blast in Hiroshima in r945. After lighting the Olympic flame in the main stadium, pigeons symbolizing peace were released to signal a new Japan. The new Japan was intent on rebuilding industries and concentrating on economic goals. The success of the women's volleyball team showed how the pressure to succeed was great. The high achieving spirit of many Japanese was reflected in both sport and in industry. It was as if the Olympics were a metaphor for what Japan had become.

The opening of the film is particularly powerful, juxtaposing as it does old and new facets of Japan. It begins with a bright sun (read Japan) and the destruction of old buildings to make way for the new (read postwar modernization). Like

Riefenstahl's film, there is an attempt to create linkages with classical Greek culture. In Ichikawa's production, a shot of Greece reminds viewers of the origins of the Olympics, and then we are transported back to Japan with another shot of a rising sun. The Olympic torch travels through Istanbul, Beirut, Tehran, Lahore, New Delhi, Rangoon, Hong Kong, and other countries. We then are reminded of Japan's past with an aerial view of Hiroshima's A-Bomb Dome. Young and old Japanese faces greet blonde foreigners coming off a Pan American jet. The torch is carried through an old Japanese town, tiled roofs of old houses flagging traditional Japan, helped along by a glimpse of bunraku puppet heads.

We return to signs of Japan's emerging modernity with the jostling and bustle of Japanese waiting to greet the foreigners in Tokyo for the Olympics. An image of Mount Fuji fills the screen, with what appears to be a vehicle zooming across the 
foreground. The car signals youth and speed, just like the international athletes visiting what clearly is a modern Tokyo. The raising of flags reinforces the image of an international event, as does the parade of countries in the opening ceremony. This internationalist theme can also be seen in Riefenstahl's Olympia, for Nazi Germany, like postwar Japan, was keen to convince the world of its peaceful intentions. $3^{8}$

The camera captures the face of Emperor Hirohito, his son Prince Akihito, and the face of an unknown old man overcome with emotion. Like the Japanese viewers of the film, he no doubt was conscious of how far the Japanese had come. While visions of the past might well have been going through his mind, a shot of a Seiko clock indicating that it was $2 \mathrm{pm}$ firmly locates us back into the present. Economic concerns are not far away. Is this an early example of indirect cinematic merchandizing? The opening of the Olympics by the Emperor, the arrival of the torch bearer, the lighting of the flame, and the release of pigeons, all serve to create a cathartic sense that we are witnessing something quite special.

Each scene seems to serve the purpose of making us aware of the coexistence of tradition and modernity. While this might be disorienting for some Japanese, such as the old man, there appears to be no looking back. The only old building remaining is that of a building in Hiroshima which serves as a reminder that Japan had been a victim. The only image of
Japan as an aggressor that we are left with is as a competitor in sport. The film provides an idealistic, easy-to-understand metaphor for Japan's reconstruction, its return to the international community, and subsequent high economic growth.

Much of the remainder of the film focusses on the athletes, their performances, and national affiliations. We could be anywhere, and perhaps that is a hidden message as well. There appears, at first, to be no radical difference that might set Asian modernity apart from that in the West. We are, however, occasionally reminded that we are in smoggy, fastdeveloping Japan, a land of tradition where some women still wear kimono. There still seems to be some traces of exotic Japan, but much of it is a thing of the past. Japan was achieving the standardization and uniformity of industrialized nations elsewhere. Gone are the mass drills of wartime. In postwar Japan, considerable effort was being made to make sport more 'scientific' and less ideologically-based.

We gaze at the bodies of athletes in a way somehow different from that of Riefenstahl's Olympia. Gone is the eugenicist quest for a perfect body, and instead we see bodies of all shapes excelling in competition. We witness the excitement of the men's roo metre freestyle swimming race, and then glimpse more of the countryside thanks to a cycling event. Women's volleyball is one of the few opportunities for us to see the 
raising of the Japanese flag, before the film closes with a ceremony and fireworks. Japan actually won sixteen gold medals, the third largest number after the USA and the Soviet Union. Japanese success served to reinforce growing pride in their achievements, in both sport and the world of trade.

The Japanese who attended the Olympics, the hordes of people who viewed Ichikawa's film, and those who were passengers on the shinkansen, all were treated to a visual spectacle which destabilized previous modes of perception. They were presented with images framed by the sporting arena, screen, or high-speed train window.39 For those who watched the film years later on television, the film served to transform the Japanese memory of the Olympics into a visual archive of filmed or remembered moments.

To commemorate the Olympics, Fuji Photo Film Co. published an album of selected photographs from that year's annual photo contest sponsored by the company. The themes for the contest were 'Youth of Japan' and 'Scenery of Japan'. While large group photographs of bodies in action were plentiful, the previous emphasis on recording mass formations was replaced by depictions of 'youthful energies, $4^{\circ}$ blurred images, smiling faces and bodies out of synchronization with each other. The photographs were used to decorate the rooms of the Olympic Village, and members of Olympic teams and officials were presented with copies of the album. Fuji Film's publication provided in book-form what Ichikawa sought to achieve on film. Both are powerful statements about how the Japanese saw themselves in the postwar period. Ichikawa, and the photographers who were selected for Fuji's album sought to change perceptions of the Japanese by framing the body in images which emphasized individualism, something which they associated with democracy and the West.

\section{RECONSTRUCTING TOKYO}

How has space changed the way the Japanese have experienced modernity? Yoshimi Shunya has explored the structural transformations of urban culture in the process of modernization, focussing especially on sakariba, parts of Tokyo where people enjoyed going to the theatre, viewed exhibitions, went shopping, and ate and drank. He argues that the shift of interest for young people from Asakusa to Ginza in the I92os (and Shinjuku to Shibuya during the I97os), reflected similarities in the sense of spatiality, the people who gathered there, and reflected the commercialization of the lives of urban dwellers. ${ }^{4}$

The ${ }_{19} 64$ Summer Olympics also changed the way in which people used the space of Tokyo. It was both a chance to introduce to the world Japan's reconstructed capital city and a stimulus to further transform areas of Tokyo adjacent to the Olympic 
site. Homes and businesses were relocated for the creation of 'Olympic

Thoroughfares'. Omotesandô-dôri, the main street going through Harajuku, was widened and made into a tree-lined boulevard which many Tokyoites refer to as their version of the Champs Élysées in Paris. Harajuku became a magnet for foreigners and Western fashion. The changes which Tokyo underwent were facilitated by the fact that Azuma Ryûtarô was governor of Tokyo from 1959 until after the Games, and also Chairman of the Japan Olympics Committee..$^{2}$

In a way, the 1964 Games were a substitute for the cancelled r940 Olympics. The continuities between wartime Japan and postwar Japan can be seen in the appropriation of army land for sporting events. What had been a drilling ground for the Japanese army became a main base of operations for the Allied Occupation and renamed 'Washington Heights'. Much of Washington Heights became an athletes' village during the Olympics and was returned to the people in the form of Yoyogi Park.43

A constant reminder of the Olympic years is the National Gymnasium complex (consisting of two buildings) designed by Tange Kenzô. Tange was one of the main authors of 'Tokyo Plan ig6o' which proposed to prepare Tokyo for the Olympics and solve some of the city's urban problems. The roofing of the main building was at once both reminiscent of Mt. Fuji and symbolic of modern Japanese architecture which drew on traditional Japanese design motifs. 44 While many of the changes to the landscape imbued the space of Tokyo with a Western-inspired modernity, the building was a potent reminder of Japanese culture, albeit distilled.

The redevelopment of Tokyo included an expanded road system, new parks, improved water supply system, bullet train, monorail line, expansion of subways, more hotels, and the Olympic site itself. The need to transport overseas visitors arriving in Japan swiftly to their destinations meant the creation of extra infrastructure which later benefited all Japanese. The Haneda Monorail Line opened less than a month before the Games and carried visitors from Tokyo's main airport to link up with the Yamanote Loop railway line. Similarly, the bullet train (shinkansen) dates from around the same time; a lasting reminder to all visitors to Japan of the country's modernity: its efficiency and technological know-how. 45

\section{RESPONSE OF OVERSEAS VISITORS}

In Olympic Diary: Tokyo 1964, Neil Allen provides a day-by-day account of his experience of the Games. His first entry for Tokyo is dated Sunday, 4 October and begins with a poem by the Emperor Meiji which highlights how Japan has long been the site where things both foreign and native came together: 
In my garden

Side by side

Native plants, foreign plants,

Growing together..$^{6}$

Allen then relates how disorienting being in Tokyo was. The Olympic site was like 'a private lung of its own', outside of which was the sprawling metropolis, the maze of streets, where 'someone who could not speak Japanese might well be lost for days'. ${ }^{47}$ In his final entry, almost three weeks later on 24 October, Allen sums up his experience with the following words:

The Japanese organization has been superb. The television aids, the electronic gadgets, the thousands of voluntary helpers and the eagerness of the ordinary public of Tokyo have seen to that. But there has been some inflexibility and we saw it again this evening when those who made rules were really asking for trouble..$^{8}$

Allen leaves us with a sense of Japan as a modern nation, with a large population which enthusiastically supported the Games, but which has little tolerance for those who do not conform to regulations.

Christopher Brasher's account Tokyo Ig64: A diary of the XVIIth Olympiad is dedicated to the British athletic team. It focuses on their performances, with little mention of Tokyo. He, like Allen, refers to the bustle of the city, 'the traffic is appalling, building is going on everywhere, Tokyo is an ugly city'. Within this city where 'the taxi-drivers do drive like kamikaze pilots' he compliments the Japanese on having created peace and tranquility in the form of the Olympic Village.49 He draws on various stereotypes of Japanese culture, to frame his impressions of the bustling city. The reference to kamikaze taxidrivers is repeated a few pages later, with a comment on how they commit seppuku (suicide) $!^{\circ}$ He describes the opening ceremony as 'the most brilliantly organized spectacle ever held in international sport ${ }^{\prime}{ }^{1}$ and devotes the remainder of the book to 'the proper business of the Games-sport between the nations of the world' ..$^{2}$ Like Allen, he congratulates Japan on its impeccable organization of the Games, but as can be seen by the contents of the book, 'the staging of the Games is, after all, no more than a setting for the athletes'. ${ }^{53} \mathrm{He}$ describes how in the closing ceremony, nationality is forgotten.

\section{GENERIC BODIES/FLUID IDENTITIES}

For postwar Japan, the 1964 Olympics helped to internationalize Japan as it emerged from defeat and reconstruction. Japanese and overseas visitors alike realized the poignancy of that moment in Japanese history, aware that Japan was still very much in the process of becoming a modern nation. Shortly after the Games ended, an issue of the illustrated Japanese magazine Mainichigurafu (Mainichi Graphic) proclaimed that "'The World is One' is not a mere phrase but living reality'.54 Japan's internationalism was pushed to the fore. Symbolic of this was a set of black and white postcards issued by the Tokyo Legal Affairs Bureau which 
emphasized the equality of all people. A generic person of no visible nationality (although obviously a man) is shown (see figure 5), as if to illustrate the universality of the human experience, as alluded to by Brasher's account.

In Japan, strict binary constructions such as tradition versus modernity are called into question. What we are rather uneasily left with is a type of ideological instability. This instability can be seen in advertising strategies. At a recent HRC conference, Yoshimi Shunya argued that in the years following the games, in the late 1960 s and r97os, advertisements for electric appliances such as television sets, refrigerators, and washing machines emphasized the influence of Japanese culture (in terms of choice of colour, craftsmanship and affinity with nature) despite the products owing much to
Western know-how. This reflects a consciousness among the Japanese that although they often borrowed ideas from elsewhere, considerable time and energy were expended in making the ideas their own. From the i 98 os, electronics became decontextualized from national space. Instead, users of technology moved around the world. 55 This is perhaps just as well, as technology labelled 'Japanese' was increasingly being manufactured offshore and there were no barriers as to who could consume the products.

\section{CONCLUSION}

This essay has shown that elements of nationalism and internationalism, ${ }^{5}$ tradition and modernity, authoritarianism and democracy have been part of Japanese attitudes to the body since late last century. Participation in the Olympics involved the

\section{FI GURE 5}

'All people are equal under the law...', Jinken yôgo (The Protection of Human Rights) black and white picture postcard series (Tokyo: Tokyo Legal Affairs Bureau, no date).

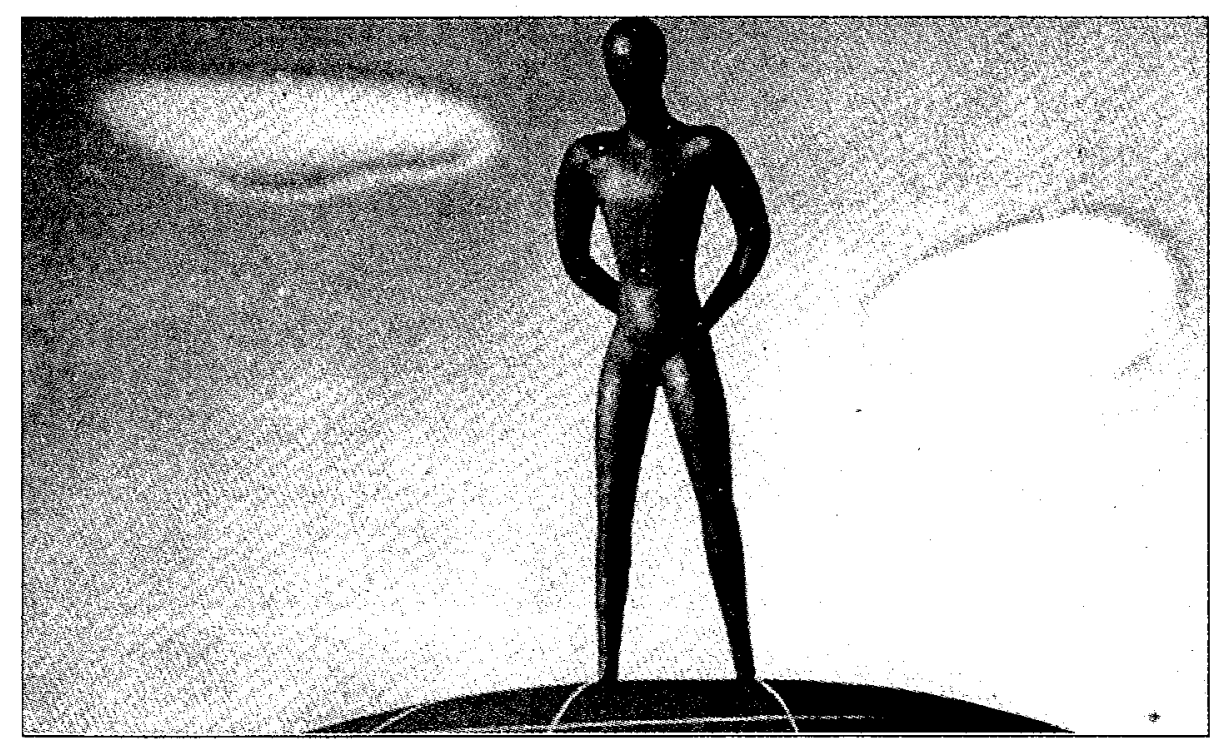


introduction of sports and obeying rules of competition. Through these rules and regulations, the Games helped create a world culture of the body where nationality was a sub-text. ${ }^{57}$ The 1964 Tokyo Olympics enabled Japan to present a new image to the world, one more inkeeping with its postwar priorities. It also spurred on the development of Tokyo, transforming it into a city, a space with modern infrastructure.

The Olympics ostensibly helped draw the line between the hardship of the immediate postwar years, and a more prosperous future, courtesy of high economic growth. Advertising images, photographs, films, and even the view from the train window, all referred to in this essay, were powerful modes of representing modernity in Japan.$^{8}$ These representations and written accounts of the 1964 Tokyo Olympics reveal to us how the Japanese were readmitted to the family of nations. But as we have seen, many Japanese and foreigners left the Games knowing that the Japanese were somehow different, for the modernity which emerged was of their own making, one which successfully coupled both local and global worlds. We are coming to realize that there are many modernities in Asia, and that the world is not all the same. As Tani Barlow has found, Asian modernities 'perform their own recodings of the discourses of modernity'.59

Media representations of the Olympics provide a window to understanding how host nations portray themselves. In the case of Japan, identity seems somewhat fluid. What will the Sydney 2000 Olympics say about Australian identity? The 1956 Melbourne Olympics provided Australia with an opportunity to perform on the international stage, and to define itself. ${ }^{60}$ Since that time, the forces of globalization have changed the way Australians view themselves. ${ }^{6}$ How will the Sydney Olympics be remembered? As the foreign visitors to the 1964 Olympics reported, it is often not so much 'place' but individual moments (of sporting excellence) which may stay in the memory. Will this be the case in 2000 ? By examining images of the sort described in this essay, we can understand how the mass media help us to frame the past and our identity in ways we are just beginning to understand. $\infty$

\section{MORRIS LOW}

Morris Low is Senior Lecturer in Asian Studies at the University of Queensland. He is a historian of Japan and has published extensively in the history of science and technology. This essay is part of a larger project on the history of Japanese visual culture and representations of masculinity.

\section{ACKNOWLEDGMENTS}

I am grateful to two anonymous readers whose constructive comments helped me to substantially revise this paper.

\section{NOTES}

' Tani E. Barlow (ed.), Formations of Colonial Modernity in East Asia (Durham, N. Carolina: Duke University Press, 1997). 
2 Jean Comaroff and John Comaroff,

'Introduction' in Jean Comaroff and John

Comaroff (eds), Modernity and Its

Malcontents: Ritual and power in

postcolonial Africa (Chicago: University of

Chicago Press, 1993), xi-xxxvii, esp. p. xii, for a discussion of modernity.

3 Yoshio Sugimoto, An Introduction to Japanese Society (Cambridge: Cambridge University Press, 1997), pp. 253-54.

4 Barlow, Formations of Colonial Modernity in East Asia.

${ }^{5}$ Sharon A. Minichiello, 'Introduction' in Sharon A. Minichiello (ed.), Japan's Competing Modernities: Issues in Culture and Democracy, rgoo-rg3o (Honolulu: University of Hawaii Press, I998), pp. I-2I, esp. p. 2.

${ }^{6}$ Ikari Seiya, 'Supôtsu: Kokusaika to taishûka' in Minami Hiroshi (ed.), Shôwa bunka: rg25rg45 (Tokyo: Keisô Shobô, r987), 504-27.

${ }_{7}^{7}$ Sabine Frühstück, 'Unveiling the Nerve of the Nation: Neurasthenia, Public Health, and the Building of Japan', unpublished paper originally presented at the Association for Asian Studies annual meeting, Washington D.C., 1998 .

${ }^{8}$ Yoshimi Shunya, 'Undôkai no shisô: Meiji Nihon to Shukusai bunka' ('The Athletics Meet: The festival culture of Meiji Japan'), Shisô, 845 (r994), 137-62.

9 Susan Brownell, Training the Body for China: Sports in the moral order of the People's Republic (Chicago: University of Chicago Press, 1995), p. 46.

${ }^{10}$ Ikari, 'Supôtsu: Kokusaika to taishûka'.

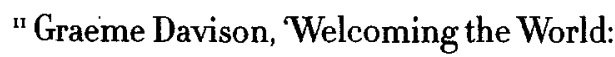
Melbourne in I956', in Juliana Engberg (ed.), r956: Melbourne, modernity and the $X V I$ Olympiad (Bulleen, Victoria: Museum of Modern Art at Heide, 1996), 49-57, p. 49.

'2 'Welcome', The Asahi Sports, May r923, p. 2.
${ }^{13}$ Grant K Goodman, 'Athletics as Politics: Japan, The Philippines and the Far Eastern Olympics of I934', Pilipinas, 2o, Spring 1993 , $55^{-66}$.

${ }_{14}$ Florence M. Taylor, $A$ Pot-Pourri of Eastern Asia: With comparisons and reflections (Sydney: Building Publishing, 1935), p. 208e. It has been suggested that the surfing individualism which Taylor was referring to also co-existed with regimentation and discipline which Taylor admired in the Japanese. See Ed Jaggard, The Australian Surf Lifesaver as a National Symbol, r9206o', in David Day (ed.),Australian Identities (Melbourne: Australian Scholarly Publishing, I998), $5^{8-72, \text { p. } 62 .}$

${ }_{55}$ Taylor, A Pot-Pourri of Eastern Asia, p. 208.

${ }^{16}$ Kenneth R. Dutton, The Perfectible Body: The Western ideal of physical development (St. Leonards, NSW: Allen and Unwin, 1995), pp. 205-9; Deobold B. Van Dalen, Elmer D. Mitchell and Bruce L. Bennett, $A$ World History of Physical Education (New York: Prentice-Hall, 1953), pp. 240-41, 342, 58o.

${ }_{77}$ Shimomura Torarokuro, Matsuda Kaizo (trans), Seinendan: Young Men's Leagues of Japan (Tokyo: Federation of the Young Men's Leagues of Japan, 1937), p. r.

${ }^{18}$ Tessa Morris-Suzuki, 'Debating Racial Science in Wartime Japan', Osiris, $\mathrm{r} 3$, in press.

${ }^{19}$ See Herbert P. Bix, 'Rethinking "EmperorSystem Fascism": Ruptures and continuities in modern Japanese history'; Gavan McCormack, 'Nineteen-Thirties Japan: Fascism?', Bulletin of Concerned Asian Scholars, 14, 2 (1982), 2-19, 20-33.

${ }^{20}$ Kaji Ryûichi, Japan: Her cultural development (Tokyo: Society for International Cultural Relations, 1939), P. 57. Japanese names are given in Japanese order throughout this paper unless the author has resided abroad for an extensive period. 
2x Tani E. Barlow, 'Editor's Introduction', Positions, I, I (I993), v-vii.

${ }^{22}$ The Society for International Cultural Relations (Kokusai Bunka Shinkokai), Sports, second impression, KB.S. Foto Series on Japanese Life and Culture, Vol. I (Tokyo: The Society, I939), pp. ii-iii.

${ }^{23}$ Edward Seidensticker, Tokyo Rising: The city since the Great Earthquake (New York: Alfred A. Knopf, r99o), pp. 102-103.

${ }^{24}$ Inoue Shun, 'Budô: Invented tradition in the martial arts' in Sepp Linhart and Sabine . Frühstück (eds), The Culture of Japan as Seen Through its Leisure (Albany: State University of New York Press, r998), 83-93.

${ }_{25}$ 'International Exposition of Japan in $194^{\circ}$ to be held at Tokyo and Yokohama to Commemorate 2,6ooth Year of Founding of Japanese Empire'; The Japan Trade Review, I1.2, (March I938), 37-44, esp. p. 37 .

${ }^{26}$ Miriam Silverberg, 'Remembering Pearl Harbor, Forgetting Charlie Chaplin, and the Case of the Disappearing Western Woman: A picture story', Positions, I.I (I993), 24-76, pp. $40-41$.

${ }^{27}$ Shin Mizukoshi, 'Social Imagination and Industrial Formation of Television in Japan', Bulletin of the Institute of Socio-Information and Communication Studies, University of Tokyo, March I996, I-14.

${ }^{28}$ 'A Historical Outline of the Development of Manchurian Railways', Contemporary Manchuria, 3.3 (July 1939), 36-6r. Also see 'Manchuria's Super-Express "Asia", Contemporary Manchuria, Vol.2, no.I, 45-6o.

${ }^{29}$ Nicholas Mirzoeff, An Introduction to Visual Culture (London: Routledge, 1999), p. 29.

${ }^{30}$ O. S. Nock, Railways of the World, Vol. 5 : Railways of Asia and the Far East (London: Adam and Charles Black, I978), p. I99.
${ }^{3}$ Kamitsuka Akihiro, 'Reform of the Red-Ink Railroad', Japan Quarterly, 33.I (JanuaryApril I986), 25-30.

$3^{2}$ Aoki Kaizo, 'The National Railways', Japan Quarterly, 8.I (January-March I96I), Io6-I3, esp.p. II3.

${ }_{33}$ Article by G. Freeman Allen and R.K. Evans in Modern Railway (October I963), cited in "The Future on Rails', Japan Quarterly, I1.4 (I964), 407-ro, esp. p. 410.

34 Yoshimi Shunya, 'The Cultural Politics of the Mass-Mediated Emperor System in Japan', paper presented at the conference Dialogue with Cultural Studies, Institute of SocioInformation and Communication Studies, University of Tokyo, I996, for a discussion of how an ordinary train ride can be a highly visual experience, with advertisements for weekly mass magazines suspended from the ceiling above the heads of passengers.

35 Davison, Welcoming the World', p. 49.

${ }^{36}$ Susan Sontag, 'Fascinating Fascism', New York Review of Books, 22, I (1975), reprinted in Susan Sontag, Under the Sign of Saturn (New York: Doubleday, I980), 73-105, for a discussion of the film.

37 Stephen S. Large, Emperors of the Rising Sun: Three biographies (Tokyo: Kodansha International, 1997), p. I $9^{2 .}$

${ }^{38}$ Andrew Bonnell, 'Director's Cut', The Australian's Review of Books, 4. 5 (June I999), $5,6,27$.

${ }^{39}$ Lynne Kirby, Parallel Tracks: The railroad and silent cinema (Exeter, Devon: University of Exeter Press, 1997), pp. 250-51, for a discussion of the convergence between trains and the cinema.

$4^{\circ}$ Fuji Photo Film Co. Ltd., Japan: Tokyo Olympic Year (Tokyo: Fuji Photo Film, 1964). I would like to thank Peter Davidson for providing me with a copy of this book. 
${ }_{4}^{4}$ Yoshimi Shunya, 'Urbanization and Cultural Change in Modern Japan: The case of Tokyo', Tôkyô Daigaku Shakai Jôhô Kenjyûjo Kiyô, 48 (December 1994), 139-55; Yoshimi Shunya, Toshi no doramaturgii: Tôkyô sakariba no shakaishi (Tokyo: Kaibundô, 1987).

$4^{2}$ Roman Cybriwsky, Tokyo: The changing profile of an urban giant (Boston: G.K. Hall, 199I), pp. 9I-92.

${ }^{43}$ Cybriwsky, Tokyo, p. 9 I.

${ }_{44}$ Cybriwksy, Tokyo, pp. $9^{1}-9^{2}$.

45 Cybriwsky, Tokyo, p. 93.

${ }^{46}$ Neil Allen, Olympic Diary: Tokyo 1964

(London: Nicholas Kaye, I965), p. 6.

${ }_{47}$ Allen, Olympic Diary, p. 6.

${ }_{4}^{8}$ Allen, Olympic Diary, p. 99.

${ }^{49}$ Christopher Brasher, Tokyo 1964: A diary of the XVIIIth Olympiad (London: Stanley Paul, I964), p. r.

${ }^{50}$ Brasher, Tokyo rg64, p. 4.

${ }^{5}$ Brasher, Tokyo rg64, p. 17.

${ }^{52}$ Brasher, Tokyo Ig64, p. 19.

${ }_{53}$ Brasher, Tokyo rg64, p. 104.
${ }^{54}$ Mainich gurafu (Mainichi Graphic), special issue, 3 November I964, p. I7o. Thanks to Peter Davidson for kindly providing a copy.of this publication.

${ }^{55}$ Yoshimi Shunya, "'Made in Japan": Cultural politics of "Home Electrification" in Postwar Japan', paper presented at the 'Electronic Identities in East Asia' conference, Humanities Research Centre, The Australian National University, February 1998.

${ }^{56}$ T.J. Pempel, 'Contemporary Japanese Athletics: Window on the cultural roots of nationalism-internationalism', in Sepp Linhart and Sabine Frühstück (eds), The Culture of Japan as Seen Through Its Leisure (Albany: State University of New York Press, I998), $13-37$.

${ }^{57}$ Brownell, Training the Body for China, pp. 37, 3II.

${ }^{8}$ Mirzoeff, An Introduction to Visual Culture, p. 65 .

59 Barlow, 'Editor's Introduction', v-vii.

${ }^{60}$ Davison, Welcoming the World', p. $5^{\circ}$.

${ }^{61}$ Robert Holton, 'Globalization and Australian Identities', in David Day (ed.), Australian Identities (Melbourne: Australian Scholarly Publishing, 1998), 198-2Ir. 